\title{
QITĀL DALAM ALQURAN DAN HADIS: TINJAUAN HISTORIS DAN PRAKSIS
}

\author{
Mohamad Nuryansah \\ Institut Agama Islam Negeri Salatiga \\ nooryansah@gmail.com
}

\begin{abstract}
This paper aims at responding a critical accusation of qital concept in the Qur'an and hadith and providing analyses by using historical and practical approach. It can be argued, then, that the purposes of qital can be explained correctly as directed by both sources. At the very practical of interpretative approach, this study employs the historical, eidetic, and practical criticism. The research argues that qital or war can be applied with some criterias and ethics based on the Qur'an and hadith instruction. These criteria are (1) The nature of qitäl should be directed into God ( $\overline{\hat{i}}$ sabililläb); (2) The qitāl should be first caused by the war of the enemy, (3) The qitall is not permitted in the sacred worship places, (4) It aims to relieve the slander, (5) It is not allowed to sacrifice of other Muslims. The ethics of qitäl are: (1) It is not permitted to overreach, (2) Moslems must end the war if the enemy are surrender, (3) it is obliged to do based on the regulations and the aggrement, (4) it is not permitted to destroy.

Keywords: Qitäl, the Qur'an, Hadith
\end{abstract}

Abstrak: Tulisan ini bertujuan untuk meluruskan pemahaman tentang qitäl dalam al-Qur'an dan hadis melalui tinjauan historis dan praksis, sebab selama ini pemahaman terhadap qitäl masih sering disalah fahami. Penelitian ini menggunanakan tiga kritik sekaligus, yaitu kritik historis, kritik eiditis dan kritik praksis. Berdasarkan ayat-ayat dan hadis Nabi maka dapat disimpulkan bahwa qitäl atau perang dapat dilakukan: (1) Qitāl murni fi sabilillah, (2) Qital ditegakkan sebab diperangi terlebih dahulu, (3) Qitāl tidak diperbolehkan di tempat ibadah, baik tempat ibadah umat Islam atau tempat ibadah non-Islam, (4) Qitāl bertujuan untuk menghilangkan Fitnah, (5) Qitāl tidak diperbolehkan mengorbankan umat Muslim yang lain. Sedangkan etika qitāl berlandaskan al-Qur'an dan hadis; (1) Qitāl tidak diperbolehkan melapaui batas, (2) Menghentikan perang apabila musuh sudah tidak berdaya, (3) Dalam Qitāl harus taat asas (peraturan) dan kesepakatan, (4) Qitāl bukan untuk merusak.

Kata kunci: Alquran, Hadis, Qitâl 


\section{Pendahuluan}

Radikalisme dan terorisme yang terjadi paska era reformasi Indonesia menjadi persoalan yang amat krusial. Salah satu penyebabnya adalah pemahaman yang keliru terhadap doktrin-doktrin keagamaan, khususnya terkait arti jihad yang dianggap sebagai bentuk pemahaman untuk berperang (qitāb). ${ }^{1}$ Spirit jihad qităl yang dilakukan oleh Nabi dan sahabat pada saat itu dirasa sangat berbeda dengan spirit jihad qitäl yang difahami oleh sebagian umat Islam saat ini, karena saat ini jihad qităl menjadi salah satu penyebab berbagai macam tindakan yang tidak ramah terhadap nilai-nilai kemanusiaan. Lebih dari itu, konsep jihad qitäl yang berlandaskan ayat-ayat Alquran dan hadis dianggap menjadi sumber utama radikalisme dan terorisme. ${ }^{2} \mathrm{Hal}$ tersebut jelas bertentangan dengan misi damai Nabi Muhammad sebagai rahmat bagi seluruh alam. Dalam QS. al-Anbiyä' [21]: 107: "Dan kami tidak mengutusmu (Muhammad) kecuali untuk menjadi rahmat bagi seluruh alam." Demikian juga hadis Nabi yang diriwayatkan oleh Imam Muslim: "Sesungguhnya aku tidaklah diutus sebagai pelaknat, namun aku diutus hanya sebagai rahmat".

Persoalan jihad qităl perlu didudukkan secara proporsional dan kontekstual pada saat ini, agar jihad qităl sesuai dengan ruh aslinya, selaras dengan nilai Islam universal sebagai raḅmat li al-'̌lamin, baik yang termaktub dalam Alquran maupun yang bersumber dari hadishadis Nabi. Apabila tidak, maka pemahaman tersebut akan sangat berbahaya sebab pemahaman tersebut dapat dianggap menjadi "satusatunya kebenaran" (the only truth) yang implikasinya merugikan, baik

1 Qitäl berasal dari huruf ل-ت Jaf, ta, lam). Menurut kamus Mujam Maqājis alLughah, kata tersebut memiliki makna menghina dan membunuh. Abū al-Husayn Aḥmad b. Fāris b. Zakaryā, Mujam Maqāyìs al-Lughah, vol. 5 (Beirut: Dār Ittiḥād al'Arabi, 2002), 56. Sedangkan qitāl sendiri berasal dari akar kata يقاتل - (qâtalayuqâtilu) yang kata dasarnya يقتل - (qatala- yaqtulu) yang bermakna membunuh, melaknat, mengutuk, memerangi, memusuhi dan berkelahi. Louis Ma'luf, Al-Munjid fi al-Lughah wa al-A lam (Beirut: Dār al-Mashriq, 2011), 608. Dengan demikian, qitāl merupakan "suatu tindakan yang berdampak pada hilangnya nyawa atau kematian seseorang.

${ }^{2}$ Moh. Nailul Muna, "Ragam Pemaknaan Jihad dalam Kitab Fatḥ al-Bârî dan Irshâd al-Sârî," dalam Mutawatir: Jurnal Keilmuan Tafsir Hadith, vol. 7, no. 2 (2017).

3 Abū Husayn Muslim b. Hajjaj al-Qushayri, Șahịḥ Muslim, "Kitāb al-Birr wa al-Ṣillah wa al-Ädāb," vol. 1 (Beirut: Dār al-Fikr, 1993), 231.

${ }^{4}$ Nurcholis Madjid, dkk., Fiqih Lintas Agama, (Jakarta: Yayasan Wakaf Paramadina, 2005), 134. 
dari aspek materi maupun hilangnya nyawa manusia, seperti peristiwa Bom Bali (2001 dan 2003) dan rentetan terorisme yang terus terjadi sampai saat ini. ${ }^{5}$

Kondisi riil tentang radikalisme dan terorisme yang berkembang di Indonesia saat ini dapat dipotret dari hasil penemuan terbaru survei dari PPIM (Pusat Pengkajian Islam dan Masyarakat) pada tahun 2017. Survei ini menyebutkan bahwa opini intoleransi dan radikalisme pada siswa di Indonesia tergolong tinggi, yaitu pandangan keagamaan yang cenderung radikal sebesar 58,5\% dan intoleran (51,1\% intoleransi internal dan 34,3\% intoleransi eksternal). ${ }^{6}$ Demikian juga survei pada 2018, PPIM menyebutkan kondisi guru di Indonesia mulai dari TK/RA sampai SMA/MA memiliki opini intoleran dan radikal yang tinggi. Sebanyak 29\% guru setuju untuk ikut berjihad di Filipina Selatan, Suriah atau Iraq dalam upaya memperjuangkan berdirinya Negara Islam. Sedangkan sebanyak 33\% guru setuju untuk menganjurkan orang lain agar ikut berperang dalam rangka mendirikan Negara Islam. Demikian juga apabila terdapat kesempatan, sebanyak $27,59 \%$ guru berkeinginan untuk menganjurkan orang lain agar ikut berperang dalam mewujudkan Negara Islam dan sebanyak 13,30\% berkeinginan untuk menyerang polisi yang menangkap orang-orang yang sedang berjuang mendirikan Negara Islam. ${ }^{7}$

Data di atas membuktikan bahwa agama yang dipandang sebagai sumber radikalisme dan terorisme tidaklah dapat diingkari. Artikel ini berusaha untuk mendudukan konsep jihad qitäl dalam sumber-sumber keislaman, Alquran dan hadis, dengan melakukan telaah reinterpretatif terhadapnya. Hal itu karena reintepretasi terhadap konsep jihad qitāl dipandang perlu untuk membangun sendi-sendi kemanusiaan dan keberagamaan bersifat asimilatif dan konstruktif.

\footnotetext{
${ }^{5}$ Menurut Yúsuf al-Qarad̄āwi, faktor utama munculnya radikalisme dalam beragama adalah cara pandang parsial dalam memahami esensi ajaran agama Islam itu sendiri dan pemahaman literal terhadap teks-teks agama. Yūusuf al-Qaradāivi, Al-Saḅah alIslamìyah bayn al-Jubüd wa al-Tatarruf (Kairo: Dār al-Shurūq, 2001), 51-57.

${ }^{6}$ Rangga Eka Saputra, Api dalam Sekam: Keberagamaan Generasi Z, ed. Endi Aulia Garadian (Jakarta: PPIM UIN Syarif Hidayatullah, 2018), 1.

7 Saiful Umam dan Yunita Faela Nisa, "Pelita yang Meredup: Potret Keberagamaan Guru Indonesia," Launching Hasil Survei PPIM 2018, Jakarta: Hotel Le Meridien, $16 / 10 / 2018$.
} 


\section{Alquran dan Hadis dalam Perbincangan Metodologis}

Kekeliruan dalam memahami dan mengamalkan doktrin qitäl menjadi penyebab utama terjadinya pertumpahan darah. qităl seoalaholah menjadi cara fundamental dalam menegakkan dan memuliakan agama Allah. Akibatnya, qităl dalam bentuk teror dan kekerasan sering dijumpai sampai saat ini, ${ }^{8}$ seperti peristiwa Bom WTC, Bali I dan Bom Bali II, Bom Thamrin, Pengeboman di Gereja, Pengeboman di Kantor Polisi dan peritiwa berdarah lainnya. Imbasnya adalah image Islam menjadi agama pedang," sehingga muncul Islam fobia di Barat. Sebagaiamana kesimpulan dari Mark A. Gabriel ${ }^{10}$ dalam bukunya Islam and Terrorism (2002), secara tegas menyatakan bahwa jihad dan perang merupakan (head of Islam) ajaran paling inti dalam Islam. ${ }^{11}$ Gabriel menilai sejarah Islam sebagai "sungai darah" (a river of blood). Sehingga Islam adalah agama yang berada di balik segala tindakan terorisme saat ini. ${ }^{12}$

Demikian juga data yang dilaporkan oleh Pattern of Global Terrorism tahun 2000. Agama Islam menempati posisi puncak sebagai agama yang melahirkan banyak terorisme dibanding dengan agama yang lain. Dalam laporan tersebut menyebutkan bahwa 43 kelompok teroris utama internasional yang terdiri dari tiga jenis kelompok: (1) berbasis religius fanatik: terdiri dari 27 sub-kelompok (18 kelompok Islam, 8 kelompok Kristen, dan 1 kelompok sekte Aum); (2) berbasis ideologi, sebanyak 12 sub-kelompok, seperti Marxisme; (3) berbasis etno nasionalisme sebanyak 4 sub-kelompok. ${ }^{13}$

\footnotetext{
8 Ahmad Syafi'i Ma'arif, "Pengantar: Mencari Akar Ekstremisme-Terorisme," dalam Azyumardi Azra, Reformulasi Ajaran Islam: Jihad, Khilafah dan Terorisme, ed. Muhammad Abdullah Darraz (Bandung: Mizan Pustaka, 2017), 21.

${ }^{9}$ Karen Armstrong, Muhammad A Biography of the Prophet (London: Victor Gollancz, Cassel Group, Wellington House, 1995), 24-26, 36-38, 164.

${ }^{10}$ Mark A. Gabriel memperoleh gelar doktor dalam bidang sejarah dan kebudayaan di Universitas Al-Azhar, bahkan pernah menjadi tenaga pengajar di Universitas bergengsi tersebut. Nasarudin Umar, "Alquran di Mata Mantan Intelektual Muslim: Ibn Warraq dan Mark A. Gabriel," dalam Jurnal Studi Al-Qur'an, vol.1 (2006): 125126.

11 Mark A. Gabriel, Islam and Terrorism; What the Qur'an Really Teaches about Christianity, Violence and the Goals of Islamic jihad (Florida: Charisme House, 2002), 24.

12 Umar, "Alquran di Mata Mantan Intelektual", 125-126.

13 Office of the Coordinator for Counterterrorism, Background Information on Terrorist Groups, Patterns of Global Terrorism-2000 (Washington: Department of State PublicationOffice of the Secretary of State, 2001), Appendix B.
} 
Berbagai peristiwa di atas tentu jauh dari semangat orisinal qităl di awal Islam, yang dilakukan oleh Nabi dan para sahabat. Sejarah mencatat bahwa setelah Nabi Muhammad melakukan hijrah dari Makkah ke Madinah, jihad qitäl menjadi wasilah perjuangan penyebaran Islam ke berbagai wilayah. Jihad qitäl tersebut di antaranya adalah: perang 'ushayrah (tahun pertama hijriah), perang badar (tahun kedua hijriah), perang uhud (tahun ketiga hijriah), perang bani nadhir (tahun keempat hijriah), perang khandaq/ahzab dan perang bani quraizah (tahun kelima hijriah), perang bani mustaliq (tahun keenam hijriah), perang khaybar (tahun ketujuh hijriah), perang hunayn dan tá'if (tahun kedelapan hijriah) serta sariyya tayyi dan tābuk (tahun kesembilan hijriah). ${ }^{14}$ Sedangkan perjalanan perang yang diikuti oleh Nabi secara langsung terjadi sebanyak 27 kali, sembilan di antaranya terjadi peperangan, sementara sisanya tidak sampai terjadi kontak fisik. Adapun ekspedisi militer yang dikirim oleh Rasulullah sebanyak 47 kali (al-sariyah). Berbagai qităl yang terjadi pada masa Nabi jelas berbeda situasi dan kondisi dibanding dengan qitäl yang digagas dan dilakukan oleh para jihadis saat ini.

Menurut Maḥmūd Shaltūt dalam karyanya yang berjudul AlQur'an wa al-Qitäl, Islam pada hakekatnya adalah agama damai dan mengutamakan kedamaian dan keharmonisan. Adapun qitäl atau peperangan merupakan jalan terakhir yang diambil karena terpaksa dan demi kemaslahatan yang lebih besar. ${ }^{15}$ Penjelasan Shaltut di atas memberikan syarat bolehnya orang Islam menegakkan qităl namun dalam kondisi tertentu, yaitu dalam kondisi terjepit atau terpaksa dan untuk kemaslahatan yang lebih besar. Ketika dua kondisi tersebut tidak dapat dipenuhi, maka umat Islam tidak diperkenanakan menegakkan qitāl sama sekali. Sejalan dengan Mạmūud Shaltūt,

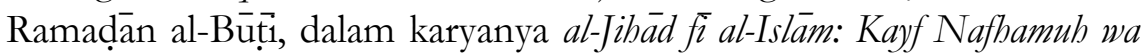
Numärisuh, menjelaskan bahwa peperangan adalah jalan terakhir untuk dilakukan. Namun di sisi lain al-Büți mengidolakan adanya dăr al-Isläm,

14 Muḥammad 'Abd al-Mālik b. Hishām, Al-Sïrah al-Nabañìah, ed. Jamāl Thābit, dkk. (Kairo: Dār al-Hadi, 2004), vol. 2: 445, 451; vol. 3: 17, 131, 153, 167, 221, 245; vol. 4: 339, 370, 397. Lihat juga 'Izz al-Din 'A $\overline{l i}$ b. Muhammad al-Shaybāni b. alAthï, Al-Kämil fí al-Tárikh, vol 2 (Beirut: Dār al-Ṣadr, 1979), 112, 116, 148, 173, 178, 192, 216, 261, 266, 276, 285. Penulis tidak menghitung tahun $11 \mathrm{H}$., sebab tahun tersebut praktis tidak ada perang, karena Nabi wafat di triwulan pertama tahun 11

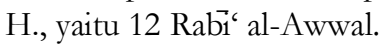

${ }^{15}$ Maḥmūd Shaltūt, Al-Qur'ān wa al-Qitāl (Beirut: Dār al-Fath, 1983), 45. 
bahkan kewajiban mempertahankannya meski melalui peperangan jika dimungkinkan. ${ }^{16}$

Adapun menurut Khayr Haykal dalam karyanya al-jibäd wa alQitäl $\overline{f i}$ al-Siyasah al-Shariyah, qital atau perang terbuka bisa dilakukan jika terdapat kafir ḩarbi (yang perlu diperangi karena mereka menabuh genderang perang). Bahkan menurutnya, apabila negeri Islam terancam, maka qitäl dapat dilakukan secara personal tanpa menunggu komando pemerintahan yang sah. ${ }^{17}$ Konsep qitäl oleh Haykal ini sangat berbahaya, bahkan dapat melahirkan berbagai bentuk teror dan kerusakan. Hal itu karena seseorang dengan subjektifitasnya, dapat melakukan tindakan teror dan qital atau peperangan hanya berdasarkan asumsi yang dangkal. Tentu hal tersebut tidak dapat dibenarkan.

Upaya pembacaan ulang atas ayat-ayat dan hadis-hadis qităl dapat dilakukan melalui tiga bentuk kesadaran. Pertama: kesadaran historis (al-sbu'ür al-tärikhi), yang bertujuan untuk menentukan keaslian sebuah teks dan tingkat kepastiannya. Kedua: kesadaran eiditis (al-shu'ur alta'ammuli $)$, yang bertujuan untuk menjelaskan makna teks dan menjadikannya sesuai dengan akal atau rasional. Ketiga: kesadaran praksis (al-shu'ür al-'amalī), yang bertujuan untuk menerapkan makna tersebut sebagai pijakan utama dalam tindakan praksis saat ini.

Kritik historis memiliki kontribusi yang vital dalam memahami ayat Alquran dan hadis. Terlebih tentang hadis, bahwa keotentikan suatu hadis harus jelas agar mendapatkan pemahaman yang benar. Sehingga validasi terhadap keotentikan hadis menjadi langkah awal sebelum melangkah ke tahap berikutnya, apakah hadis tersebut sahih atau hasan atau daif. Keaslian teks agama harus diuji melalui kajian kritik hitoris atau kesejarahan bukan berdasarkan asas keyakinan, teologis, filosofis maupun spiritual mitis. Hal itu karena hadis adalah entitas yang memiliki latar historisnya, sehingga pembacaan historis terhadapnya perlu dilibatkan sebagai pelengkap dari model pembacaan normatif.

Dalam melakukan validasi sebuah hadis, maka dilakukan kritik

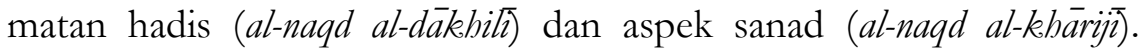

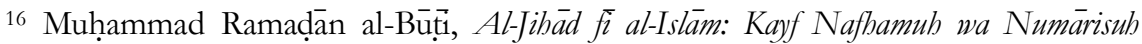
(Libanon: Dār al-Fikr al-Mưa ạsir, 1993), 56.

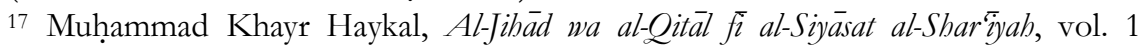
(Damaskus: Dār al-Bayāriq li al-Ṭibā‘ah, 1996), 260.
} 
Sebab kedua aspek tersebut saling keterkaitan dan tidak dapat ditinggalkan. Maka kaidah baku yang telah disusun oleh para ahli hadis wajib ditempuh dalam melakukan analisis kritik sanad (al-naqd al-khärijī atau al-naqd al-z̧ähiri $)$ dan analisis kritik matan (al-naqd aldākhili atau al-naqd al-bätinī).

Arti "kritik hadis", baik sanad maupun matan hadis, tidak sama dengan istilah "kritik" dalam ilmu sosial (social science). Sebab kritik ilmu sosial lebih diartikan sebagai sebuah kecaman yang kadangkadang disertai uraian terhadap pertimbangan baik buruk terhadap suatu hasil karya, pendapat, dan sebagainya. Adapun tujuan kritik dalam ilmu sosial adalah melakukan pembongkaran terhadap wacanawacana untuk mengungkap sisi lain dari berbagai persoalan. Kritik diarahkan untuk menyelidiki kemungkinan-kemungkinan baru dengan mengungkap suatu unsur, sisi, level atau wilayah wujud. Teori kritik pertama kali dikembangkan oleh Horkheimer, Marcuse, Theodor Wiesengrundadorno dan Jurgen Habermas. Teori ini merupakan teori kritik masyarakat yang intinya bermaksud membebaskan masyarakat dari manipulasi keilmuan modern. Titik temu yang menyimpulkan tokoh-tokoh teori kritik adalah upaya untuk merumuskan suatu teori yang bersifat emansipatoris. Meskipun terminologi kritik telah digunakan oleh para pendobrak dominasi otoritas gereja sejak masa renaisans, namun term kritik menemukan signifikansinya pasca lahirnya empat filosof besar: Immanuel Kant, Friederich Hegel, Karl Marx, dan Sigmund Freud. ${ }^{18}$ Setelah itu, di Jerman, di Inggris dan di Prancis berkembang subur teori kritik, begitu juga dalam dunia Islam seperti dapat kita temukan dalam beberapa pemikir seperti Naṣr Ḥāmid Abū Zayd, ‘'̄bid al-Jābirīi dan Muḥammad Arkoun.

Adapun tradisi pemakaian kritik (naqd) di kalangan ulama' hadis didefinisikan sebagai sebuah upaya menyeleksi (membedakan) antara hadis sahih dan daif dan menetapkan status perawi-perawinya dari segi kepercayaan dan cacat." 19 Dengan kata lain, kritik hadis adalah "penetapan status cacat atau adil pada perawi hadis dengan menggunakan idiom khusus berdasarkan bukti-bukti yang mudah diketahui oleh para ahlinya, dan mencermati matan hadis sepanjang sahih sanadnya, untuk tujuan mengakui validitas atau menilai lemah

18 Fransisco Budi Hardiman, Kritik Ideologi: Pertautan Pengetabuan dan Kepentingan, (Yogyakarta: Kanisius, 1992), 175.

19 Muhammad Muṣtafa al-A'ẓami, Manhaj al-Hadith 'ind al-Mubaddithin: Nash'atub wa Tarikhuh (Makkah: Maktabat al-Kawthar, 1990), 5. 
dan upaya menyingkap kemusykilan pada matan hadis yang sahih, serta mengatasi gejala kontradiksi antar matan dengan mengaplikasikan tolak ukur yang detail."

Dalam menentukan kesahihan sanad hadis para ulama' menetapkan lima unsur yang harus dipenuhi: (1) sanad yang bersambung, (2) seluruh perawi bersifat adil, (3) seluruh periwayat bersifat dabit, (4) hadis terhindar dari shädh, dan (5) hadis terhindar dari 'illat. Sedangkan dalam menentukan kaidah kesahihan matan hadis, maka ada beberapa hal yang harus diperhatikan, mengingat bahwa matan hadis terdiri dari dua unsur penting, yaitu (1) unsur lafaz atau teks dan (2) unsur makna atau interpretasi. Oleh sebab itu susunan lafaz atau kalimat pada sebuah hadis berfungsi sebagai sarana untuk menggali makna yang diinginkan oleh hadis tersebut. Sebab hadis memiliki banyak versi lafaz atau matan, namun sama maknanya, sebab hadis dapat diriwayatkan secara bi al-riwayah. ${ }^{20}$

Adapun kritik matan hadis dapat dilakukan dengan tiga langkah: (1) analis kebahasaan. Langkah ini bertujuan untuk mencermati orisinalitas dan kebenaran dari teks hadis, agar terhindar dari pemalsuan dan upaya munculnya kepercayaan akan kebenaran teks hadis. ${ }^{21}$ (2) analisis kandungan isi pada matan hadis. Langkah ini bertujuan untuk memotret isi kandungan hadis apakah layak untk diamalkan, atau dikesampingkan atau di maukufkan. (3) analisis ulang nisbah (asosiasi) dalam matan hadis kepada narasumber. Langkah ini bertujuan untuk menelusuri potensi kehujahan hadis dalam pembentukan aturan syariat. ${ }^{22}$ Sedangkan menurut al-Khatịib alBaghdādi, matan hadis dapat dikatakan makbul apabila memenuhi beberapa syarat: (1) Tidak bertentangan dengan akal sehat; (2) Tidak bertentangan dengan Alquran; (3) Tidak bertentangan dengan hadis mutawatir; (4) Tidak bertentangan dengan hadis ahad yang lebih kuat kualitasnya; (5) Tidak bertentangan dengan amalan yang telah ditentukan oleh ulama salaf; dan (6) Tidak bertentangan dengan dalil yang lebih pasti $(q a t \cdot \bar{r})^{23}$

\footnotetext{
${ }^{20}$ Salahuddin ibn Ahmad al-Adlabi, Metologi Kritik Matan hadis (Jakarta: Gaya Media Pratama, 2004), 30.

21 Ibid.

22 Mujammil Qamar, Kritik Teks Hadis: Analisis Tentang al-Riwayah bi-al-Ma'ani dan Implikasinya bagi Kualitas Sanad (Yogyakarta: Teras, 2009), 9-11.

23 Al-Khațib al-Baghdādi, Kitāb al-Kifayah fí $\mathrm{Tlm}$ al-Riwayah (Mesir: Matba'ah alSa áadah, 1972) 432.
} 
Kritik historis menjadi sangat penting, terutama untuk hadis, sebab hadis tidak sama dengan Alquran. Alquran bersifat mutawatir sehingga bersifat qat $\bar{i}$ al-wurüd, sedangkan hadis bersifat zanni al-wurüd. Ia ditransmisikan melalui sistem riwayat (sanad) dari generasi ke generasi dan disampaikan dengan tradisi lisan (verbal). Alquran semuanya mutawatir, sedang hadis tidak semuanya mutawatir. Hadis melewati tiga tahap, yaitu melalui tradisi pengalihan lisan (verbal transmission), kemudian tradisi pengalihan praktik (practical transmission) dan tradisi pengalihan tulisan (textual transmission). Waktu yang dibutuhkan dari tradisi lisan sampai tradisi tulis (kodifikasi) kurang lebih 200 tahun, ${ }^{24}$ sehingga hadis bersifat zanni al wurud. ${ }^{25}$

Selanjutnya, melakukan kritik eiditis dengan tiga langkah utama: ${ }^{26}$ (a) Analisis isi yaitu pemahaman terhadap matan hadis melalui kajian linguistik. Kajian linguistik yang dimaksud adalah menganalisis isi hadis dengan menggunakan aturan main dan kaidah-kaidah baku bahasa Arab. Sebab bahasa asal yang digunakan dalam Alquran dan hadis merupakan bahasa Arab. Misalnya menyangkut bentuk kata (sighah) atau arti kata (murād), juga terkait penggunaan kata kerja, kata benda, bentuk perintah atau larangan, antara makna haqiq $\bar{i}$ dan maja $\bar{i}, \bar{i}$ antara makna ' $\bar{a} m$ dan khass, mutlaq dan muqayyad dan lain sebagainya. Hal tersebut penting untuk dilakukan agar kajian bersifat tematis komprehensif. ${ }^{27}$ (b) Analisis atas realitas historis. Setelah menemukan makna tekstual dari hadis yang dikaji melalui analisis isi, selanjutnya melakukan penelusuran terhadap konteks sosio-historis hadis, yaitu memahami ayat dan hadis qităl dengan melibatkan sejarah dan kondisi sosial masyarakat saat hadis itu muncul. ${ }^{28}$ Pada tahapan ini, peneliti hadis tidak hanya melibatkan realitas faktual pada saat hadis tersebut

${ }^{24}$ Suryadi, "Rekonstruksi Metodologi Pemahaman Hadis Nabi," dalam ESENSIA: Jurnal Ilmu-Ilmu Ushuluddin, vol. 2, no. 1 (2001), 91.

25 Muhammad Yusuf, Metode Dan Aplikasi Pemaknaan Hadis, (Yogyakarta: Sukses Offset, 2008), 16. Lihat juga, M. Quraish Shihab, Membumikan Alquran (Bandung: Mizan, 2002), 122.

${ }^{26}$ Hanafi, Diräsät Islämìyah, 78.

27 Wasman, "Pemahaman Hadis-Hadis Konfrontatif terhadap yahudi dan Nasrani", Disertasi, UIN Sunan Kalijaga Yogyakarta, 2014, 31

${ }^{28}$ Sosio-Historis sama dengan "konteks makro" dalam pandangan Abdullah Saeed, yaitu usaha memperhatikan aspek sejarah, politik, sosial, ekonomi, kultural dan intelektual pada teks. Abdullah Saeed, Alquran Abad 21: Tafsir Kontekstual, terj. Ervan Nurtawab (Bandung: Mizan, 2016), 14. Lihat juga, Abdullah Saeed, Pengantar Studi Al-Qur'an, terj. Shulkhah \& Sahiron Syamsuddin (Yogyakarta: Baitul Hikmah Press, 2016). 
muncul, namun juga melibatkan situasi, kondisi bahkan problem historis pada saat hadis tersebut muncul. Langkah ini mewajibkan kajian kesejarahan hadis dari aspek mikro dan makro sekaligus. Kesejarahan mikro diperoleh dengan mengkaji asbāb wurüd al-hadith, sedangkan makro diperoleh dengan mengkaji situasi kehidupan masyarakat Arab pada saat itu. Kedua hal tersebut dilakukan agar tidak terjadi kesalahan dalam memahami ayat Alquran dan hadis Nabi. $^{29}$ (c) Melakukan generalisasi. Analisis isi melahirkan makna tekstual, analisis atas realitas historis melahirkan signifikansi konteks dengan realitas historis pada masa Nabi. Sedangkan melalui generalisasi dapat menemukan makna universal dari ayat dan hadis Nabi. Generalisasi yang melahirkan konstruk rasional universal semakna dengan moral sosial (ideal moral) ${ }^{30}$ yang digagas oleh Fazlur Rahman dan apa yang disebut sebagai maqāsid al-sharíah dalam pandangan al-Shạtibì dan al-Ṭûfi. ${ }^{31}$

Selanjutnya, melakukan kritik praksis sebagai upaya mendialogkan makna universal ayat dan hadis terhadap realitas dan kondisi kehidupan saat ini agar menghasilkan kontribusi positif dalam upaya penyelesaian persoalan saat ini. ${ }^{32}$ Dalam kaitan ini adalah persoalan radikalisme dan terorisme. Upaya dalam mensinergikan dibutuhkan berbagai macam cabang ilmu pengetahuan (interdisipliner), artinya tidak hanya ahli agama semata namun juga melibatkan berbagai macam pakar, baik ekonomi, politik, sosial, dan lain sebagainya. Dengan demikian diharapkan penelitian ini menemukan "makna yang aplikatif' pada konteks saat ini.

\section{Ayat-Ayat Kunci untuk Memahami Qitāl dalam Alquran}

Kata qitäl (qatal-yaqtul) muncul sebanyak 67 kali dalam Alquran. Tiga belas ayat berbentuk kata kerja perintah aktif dan selebihnya berbentuk pasif. Objek pembicaraan qital dalam Alquran tidak semata merujuk kepada orang beriman, namun juga berkaitan dengan kisah

\footnotetext{
${ }^{29}$ Komaruddin Hidayat, Memahami Bahasa Agama: Sebuab Kajian Hermeneutik (Jakarta: Paramadina, 1996), 23.

30 Fazlur Rahman, Islam and Modernity: Transformation of an Intellectual Tradition (Chichago: The University of Chichago Press, 1982), 6.

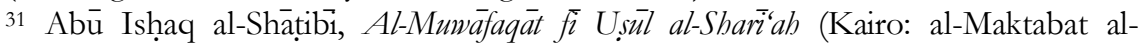
Tijāìyah al-Kubrā, t.t.), 29.

${ }^{32}$ Hanafi, Dirāät Islämìyah, 95.
} 
Bani Israil. Berbeda dengan kata jihad dalam Alquran yang selalu ditujukan kepada orang beriman dan selalu berbentuk aktif.

Qitäl merujuk pada definisi yang terdiri dari dua pihak yang berperang. Apabila hanya ada satu pihak saja maka disebut dengan istilah qatl (membunuh atau pembunuhan). Islam menggunakan istilah perang dengan qitäl bukan qatl, karena sejatinya Islam hanya akan melakukan perang ketika ada musuh atau pihak lain yang menyebabkan perang. Qitäl dalam Alquran menjadi sebuah akibat bukan sebab. Qitāl dan harb memiliki makna yang hampir serupa. Namun dalam Alquran ḅarb (băraba-yuhärib) hanya digunakan dua kali dan semuanya berkonotasi negatif, yaitu "memerangi Allah dan rasulNya".

Menurut Sahiron, ayat-ayat Alquran yang secara sepintas (direct meaning) sesuai dengan ide dan pesan moral secara umum masuk dalam kategori ayat muhkamat. Sedang ayat-ayat yang tampak sepintas bertentangan dengan ide moral merupakan ayat-ayat mutashäbibāt. Dengan demikian ayat-ayat tentang perang "yang dibolehkan" merupakan ayat-ayat mutashäbihät. Sehingga dalam konteks ini seseorang perlu berhati-hati dalam menafsirkannya. ${ }^{33}$

Ayat-ayat kunci untuk memahami qital dalam Alquran dapat dilihat adalah surah al-Baqarah [2]: 190-193, 216-217 dan QS. al-Hajj [22]: 39-40.

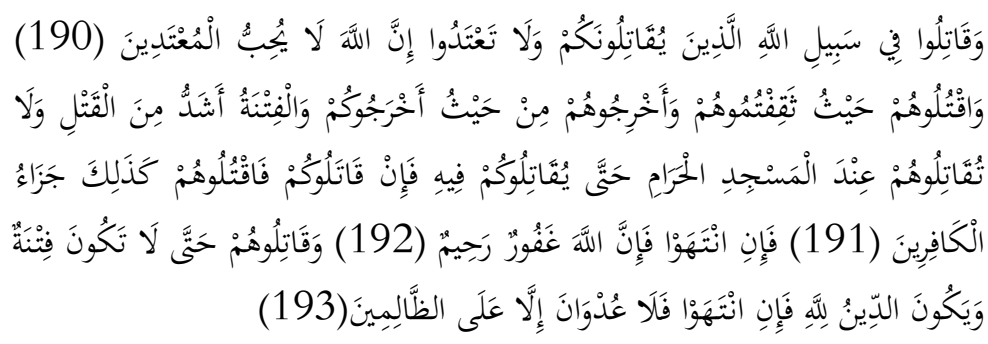

"Dan perangilah di jalan Allah orang-orang yang memerangi kamu, (tetapi) janganlah kamu melampaui batas, karena sesungguhnya Allah tidak menyukai orang-orang yang melampaui batas. Dan bunuhlah mereka di mana saja kamu jumpai mereka, dan usirlah mereka dari tempat mereka telah mengusir kamu (Mekah); dan fitnah itu lebih besar bahayanya dari pembunuhan, dan janganlah kamu memerangi mereka di Masjidil Haram, kecuali jika mereka memerangi kamu di tempat itu. Jika mereka

\footnotetext{
33 Sahiron Syamsudin, "Pesan Damai di Balik Seruan Jihad," dalam Islam, Tradisi dan Peradaban, ed. Sahiron Syamsudin (Yogyakarta: Bina Mulia Press, 2012), 87.
} 
memerangi kamu (di tempat itu), maka bunuhlah mereka. Demikanlah balasan bagi orang-orang kafir. Kemudian jika mereka berhenti (dari memusuhi kamu), maka sesungguhnya Allah Maha Pengampun lagi Maha Penyayang. Dan perangilah mereka itu, sehingga tidak ada fitnah lagi dan (sehingga) ketaatan itu hanya semata-mata untuk Allah. Jika mereka berhenti (dari memusuhi kamu), maka tidak ada permusuhan (lagi), kecuali terhadap orangorang yang zalim.” (QS. al-Baqarah [2]: 190-193)

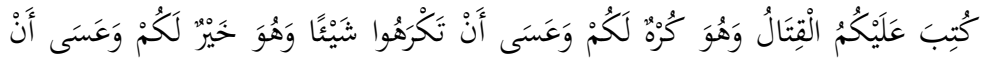

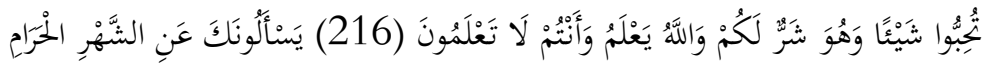

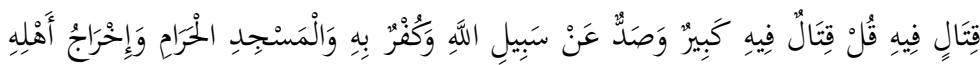

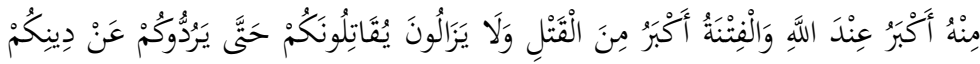

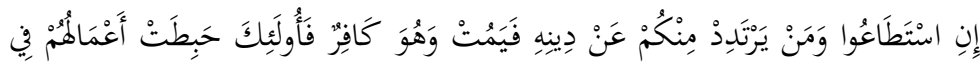

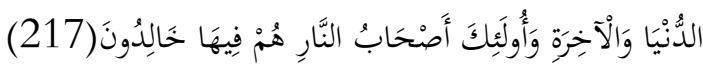

"Diwajibkan atas kamu berperang, padahal berperang merupakan sesuatu yang tidak kamu senangi. Bisa jadi kamu membenci sesuatu, padahal ia baik bagi kamu, dan bisa jadi (pula)kamu menyukai sesuatu, padahal ia buruk bagi kamu; Allah mengetahui sedangka kamu tidak mengetahui. Mereka bertanya kepadamu tentang berperang pada bulan Haram. Katakanlah: "Berperang dalam bulan itu adalah dosa besar; tetapi menghalangi (manusia) dari jalan Allah, kafir kepada Allah, (menghalangimasuk) Masjidil haram dan mengusir penduduknya dari sekitarnya, lebih besar (dosanya) di sisi Allah. Dan berbuat fitnah lebihbesar (dosanya) daripada membunuh. Mereka tidak henti-hentinya memerangi kamu sampai mereka (dapat) mengembalikan kamu dari agamamu (kepada kekafiran), seandainya mereka sanggup. Barangsiapa yang murtad di antara kamu dari agamanya, lalu diamati dalam kekafiran, maka mereka itulah yang sia-sia amalannya di duniadan di akhirat, dan mereka itulah penghuni neraka, mereka kekal di dalamnya." (QS. al-Baqarah [2]: 216-217)

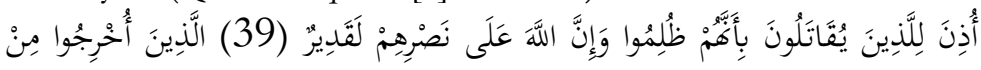

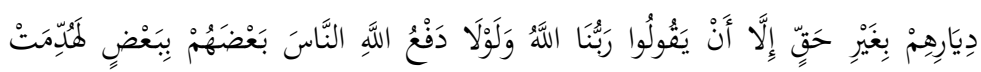

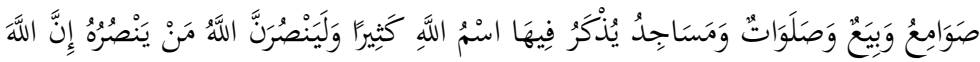

$$
\begin{aligned}
& \text { لَقَويٌٌ عَزْيزٌ (40) }
\end{aligned}
$$

"Telah diizinkan (berperang) bagi orang-orang yang diperangi, karena sesungguhnya mereka telah dianiaya. Dan sesungguhnya 
Allah, benar-benar Maha Kuasa menolong mereka itu. (yaitu) orang-orang yang telah diusir dari kampung halaman mereka tanpa alasan yang benar, kecuali karena mereka berkata: "Tuhan kami hanyalah Allah". Dan sekiranya Allah tiada menolak (keganasan) sebagian manusia dengan sebagian yang lain, tentulah telah dirobohkan biara-biara Nasrani, gereja-gereja, rumah-rumah ibadat orang Yahudi dan masjid-masjid, yang di dalamnya banyak disebut nama Allah. Sesungguhnya Allah pasti menolong orang yang menolong (agama)-Nya. Sesungguhnya Allah benar-benar Maha Kuat lagi Maha Perkasa." (QS. al-Haji [22]: 39-40)

Surah al-Baqarah ayat 190-193 di atas merupakan ayat yang turun di Madinah dan turun terkait kekhawatiran kaum Muslim terhadap serangan kaum musyrik menjelang umrah qada, Akan tetapi kaum musyrik rupanya takut menghalangi kaum Muslim yang sudah siap dengan segala kemungkinan, dan memilih untuk mengikuti isi perjanjian Hudaibiyah sehingga mereka keluar kota lima hari memberi keleluasaan bagi Rasulullah dan kaum Muslim menunaikan ibadah umrah. Kaum Muslim pun tidak berniat memulai perang, sehingga mereka tidak menggangu berhala-berhala yang masih bersandaran di Ka'bah dan tegak diantara Shafa dan Marwah. Ayat tersebut merupakan salah satu ayat yang secara eksplisit memerintahkan perang bagi orang beriman dengan beberapa ketentuan yaitu : (a) $\overline{f i}$ sabilillahb; (b) ditujukan terhadap orang-orang yang memerangi (alladbin yuqâtilinnakum); (c) tidak melampaui batas (wa là ta'taddū); (d) dengan kesungguhan/keberanian; (e) tidak melakukannya di masjid al-haram, kecuali mereka (lebih dulu) memerangi di tempat itu; (f) berhenti memerangi kalau mereka berhenti memusuhi; dan (g) sampai tidak ada fitnah lagi dan tegaknya ketaatan kepada Allah. ${ }^{34}$

Dalam Alquran penyebutan kata qital yang diiringi dengan kata $\bar{f}$ sabilillāh terdapat sebanyak tiga belas kali. Sabilillăh terdiri dari dua kata, yaitu sabīl dan Allāh. Sabīl berarti jalan, Allah bermakna Tuhan Allah. Sabilillah berarti segala amal tindakan yang bisa mengarahkan pelakunya menuju dan dekat kepada Allah. Jadi secara normatif, qital $\bar{j}$ sabilillăh adalah berperang dan berjuang hanya mengharap keridhaan Allah. ${ }^{35}$ Qitäl $\overline{f i}$ sabilillāh tidak lain untuk tujuan kebenaran, yaitu

34 Izza Rohman, "Jihad dan Qitäl dalam Alquran," dalam Reformulasi Ajaran Islam: Jihad, Khilafah dan Terorisme, ed. Muhammad Abdullah Darraz (Bandung: Mizan Pustaka, 2017), 412.

35 Abdul Aziz Dahlan (ed.), Ensiklopedi Hukum Islam (Jakarta: Ichtiar Baru Van, 1996), 76. 
memperjuangkan dan mempertahankan agama Allah. Apabila tidak, maka peperangan tersebut tidak dapat dikategorikan sebagai perang yang dijelaskan oleh Alquran dan dilakukan oleh Nabi pada waktu dulu. Meskipun narasi yang dimunculkan adalah jihad di jalan Allah, perang atas nama agama, perang membela agama dan narasi-narasi lain yang setema. Sebab belasan kali pernyataan Alquran tentang "berperang di jalan Allah," tidak satu pun yang menggunakan kalimat atau pernyataan "membunuh di jalan Allah" (qatal/yaqtulu $\bar{f}$ sabilillăh). Melainkan "terbunuh di jalan Allah" (qutila/yuqtal $\bar{f}$ sabilillāh), ini menandakan bahwa Alquran tidak menghendaki sama sekali peperangan. Namun apabila terpaksa (karena diperangi) maka Alquran menegaskan untuk melawannya.

Adapun aspek historis qităl $\bar{f}$ sabilillăh merupakan sebuah peperangan yang dapat mewujudkan rasa keadilan, kedamaian dan kesejahteraan untuk segala umat manusia. Apabila tidak, maka tidak dapat masuk dalam kategori qital $\bar{f} \bar{i}$ sabilillāh. Sebagaimana yang terus terjadi sampai saat ini, seperti pengeboman tempat ibadah agama lain, tempat belanja, kantor polisi, tentu tidak dapat dikategorikan sebagai qital $\bar{f}$ sabilillăh, sebab hal tersebut justru membuat kematian, ketakutan, dan kekacauan di negara yang damai.

Qitäl boleh dilancarkan (hanya) kepada orang-orang yang memerangi (alladhìn yuqātilünakum). Konotasi memerangi di sini adalah memerangi dalam hal agama $(\overline{\bar{i}}$ al-din), sebagaimana pesan QS. alMumtahanah [60]: 9,

"Sesungguhnya Allah hanya melarang kamu menjadikan sebagai kawanmu orang-orang yang memerangimu karena agama dan mengusir kamu dari negerimu, dan membantu (orang lain) untuk mengusirmu. Dan barangsiapa menjadikan mereka sebagai kawan, maka mereka itulah orang-orang yang zalim."

Sementara kepada orang-orang yang tidak memerangi (karena agama), QS. al-Mumtahanah [60] ayat 8 mengingatkan bahwa

"Allah tidak melarang kamu untuk berbuat baik dan berlaku adil terhadap orang-orang yang tiada memerangimu karena agama dan tidak (pula) mengusir kamu dari negerimu. Sesungguhnya Allah menyukai orang-orang yang berlaku adil."

Penegasan "diperangi dalam hal agama" membuktikan bahwa Islam memberikan batasan yang ketat dalam peperangan atau qital. Bahkan apabila dicermati saat ini, maka hampir tidak ditemukan penyerangan terhadap masyarakat Islam karena faktor agama. 
Terdapat faktor dominan lainnya yang menyebabkan, baik dari ekonomi, budaya, politik dan lain sebagainya. Agama dijadikan sebagai platuk untuk mendapatkan simpati dari para pemeluknya. Baik bersekala local maupun global. Oleh sebab itu, sebagai umat Islam hendaknya tidak mudah terprovokasi oleh hasutan-hasutan dengan mengatasnamakan agama.

Dilarang melapaui batas (wa là ta'tdadū) diartikan oleh Ibn Kathir sebagai larangan untuk tidak membunuh tuna netra, tidak membunuh orang yang tidak ikut berperang, tidak membunuh pendeta atau biarawan, tidak merusak pohon dan tidak membunuh hewan. Al-Ṭabari juga menyebutkan hal serupa yang intinya adalah ketentuan ketentuan berperang yang disebutkan dalam sunah, termasuk mendakwahkan kebenaran terlebih dahulu. Selain itu, qitäl juga tidak boleh dilakukan di tempat suci dan empat bulan suci. Sedangkan Buya Hamka menjelaskan tidak melampaui batas di sini berarti: 1) tidak memulai perang terlebih dahulu; 2) saat perang terjadi, jangan membunuh orang tua, perempuan, anak anak dan orang tak bersenjata serta tidak merusak tempat ibadah; 3) tidak membunuh orang yang telah menyerah dan tidak mencincang orang yang telah terbunuh. ${ }^{36}$

Melampaui batas merupakan perbuatan berlebih-lebihan. Islam tidak menghendaki berlebih-lebihan, dalam qitäl sekalipun. Sebab secara naluri kemanusiaan, seseorang yang menang dalam peperangan berhak melakukan apapun terhadap yang dikalahkan. Namun tidak demikian dalam Islam, sekalipun sudah pada titik kemenagan, Islam melarang tindakan-tindakan yang dapat merusak eksistensi manusia itu sendiri, seperti membunuh para pendeta, merusak pohon, membunuh hewan, membunuh anak-anak, perempuan atau memperlakukan hal-hal yang buruk (mencincang) setelah dibunuh.

Penuh kesungguhan dan keberanian dalam qităl adalah modal utama dalam qitäl. Sebab berperang merupakan suatu perbuatan yang tidak disenangi (kurb), sebagaimana penjelasan dalam QS. al-Baqarah [2]: 216. Akan tetapi, di medan perang, orang harus berani membunuh dan mengusir (QS. al-Baqarah [2]: 191). Di ayat lain, QS. al-Ṣaff [61]: 4, ditambahkan ketentuan lain, sesungguhnya Allah menyukai orang yang berperang di jalan-Nya dalam barisan yang teratur seolah mereka suatu bangunan yang tersusun kokoh.

36 Rohman, "Jihad dan Qitäl," 413. 
Kesungguhan dan keberanian merupakan hal penting dalam qitäl. Hal tersebut menunjukkan bahwa Islam tidak menghendaki peperangan, namun tidak lari ketika keadaan memaksa untuk menegakkan qităl. Bahkan dalam sebuah hadis Abū Hurayrah menyebutkan bahwa lari dalam peperangan merupakan dosa besar, setara dengan dosa syirik dan membunuh. Dari Abū Hurayrah berkata, Rasulullah SAW bersabda:

"Tinggalkanlah tujuh dosa yang akan membinasakan. Sahabat bertanya, 'Yaa Rasulullah, apakah dosa-dosa itu? Jawab Nabi, "Syirik mempersekutukan Allah, melakukan sihir, membunuh jiwa manusia yang telah diharamkan Allah kecuali dengan hak, makan riba, makan harta anak yatim, lari dari perang jihad, menuduh zina pada wanita mu'minat," (HR. al-Bukhāri-Muslim)

Tidak menyerang musuh di Masjid al-Haram kecuali mereka terlebih dahulu menyerang membuktikan bahwa Allah melarang peperangan di tempat suci. Masjidil haram pada saat ayat ini diturunkan masih penuhi oleh berhala-berhala kaum kafir Quraish. Masjid al-Haram pada saat itu dijadikan tempat ibadah, baik oleh orang muslim maupun orang kafir. Dengan demikian maka qităl di tempat ibadah tidak diperbolehkan. Baik tempat ibadah umat Islam maupun tempat ibadah agama lain. Ini adalah pesan utama dari ayat "jangan perangi mereka di Masjid al-Ḥaram” (wa là tuqâtilūbum ind almasjid al-ḥaräm).

Hamka, dalam tafsirnya Al-Az̧ar menegaskan bahwa umat manusia memiliki kewajiban yang sama dalam menjaga keamanan umat beragama. Baik menjaga keamanan umat Islam, Kristen, Hindu, Budha serta membela tempat ibadahnya, baik berupa Masjid, Gereja, ataupun Sinagog. Sebab menurut Hamka, menjaga dan membela tempat-tempat ibadah merupakan bagian dari politik luhur Agama Islam. ${ }^{37}$

Keharusan dihentikannya qităl apabila lawan berhenti memusuhi dan lawan sudah tidak berdaya merupakan bukti bahwa qităl dalam Islam tidak bertujuan merusak atau melukai, namun karena mempertahankan diri. Qitäl bukan tujuan utama, ia merupakan tindakan yang harus diambil oleh umat Islam apabila tidak dapat lagi menghindarinya. Sekiranya penyebab qitäl hilang, seperti musuh berhenti memusuhi atau musuh sudah tidak berdaya, maka qitāl tidak

${ }^{37}$ Hamka, Tafsir Al-Az̧har, vol. 3 (Jakarta: Pustaka Panjimas, 1986), 272. 
boleh dilanjutkan. Demikian pula manakala musuh sudah tidak berdaya tentu fitnah ${ }^{38}$ tak ada lagi.

Berdasarkan penjelasan qităl dalam QS Al-Baqarah (2): 190-193 dapat disimpulkan bahwa qitäl bukan untuk mengizinkan kekerasan, tetapi untuk membatasi (atau mencegah) kekerasan. Ini tentu jauh berbeda dari qitäl yang digagas oleh kalangan ekstremis yang justru menciptakan kematian, kekacauan, kekerasan dan menimbulkan fitnah bagi agama Islam.

Adapun dalam QS. al-Baqarah [2]: 216-217 dijelaskan tentang dua hal, mengakui naluri manusia normal yang tidak suka dengan peperangan dan membela Agama Islam. Naluri manusia normal tentu tidak menghendaki adanya peperangan, sebab perang dapat menyebabkan hilangnya nyawa, harta dan benda. Oleh sebab itu tidak ada satupun naluri manusia yang menghendakinya. Namun perang harus dilakukan manakala keadaan sudah mengharuskannya. Hal tersebut dapat dilihat dari kata "kutiba" yang bermakna "diwajibkan". Qitāl menjadi keharusan ketika musuh yang terlebih dahulu menyerang atau musuh sudah memasuki sebuah wilayah, maka wajib tiap muslim untuk membela tumpah darahnya yang merupakan tempat menerapkan nilai-nilai ilahi. ${ }^{39}$

Ayat di atas jelas bahwa perang bukan "keinginan" umat Islam. Meskipun menggunakan kata "kutiba" (diwajibkan) namun kata tersebut berlaku manakala dalam kondisi-kondisi tertentu sebagaimana dalam QS. al-Baqarah [2]: 190-193 di atas. Ketidaksukaan perang oleh umat Islam pada ayat di atas di tandai dengan kata "kurb" (sesuatu yang dibenci). Sehingga anggapan sarjana Barat bahwa Islam merupakan agama yang senang dengan kekerasan dan peperangan merupakan kesimpulan yang salah.

Adapun surat QS. al-Hajj [22]: 39-40, merupakan ayat pertama yang memberikan izin untuk berperang. Sebagaimana pendapat yang dikemukakan oleh 'Alì al-Ṣäbūni yang mengutip riwayat dari Ibn 'Abbās, ${ }^{40}$ Allah memberikan izin memerangi orang-orang kafir karena alasan kezaliman dan penindasan yang mereka lakukan kepada kaum

\footnotetext{
38 Fitnah adalah 'hasutan, hambatan, gangguan dan siksaan yang ditimpakan oleh orang-orang kafir kepada kaum muslim'. Ibn Kathir menyebutkan bahwa fitnah di sini adalah kekufuran, kesyirikan dan tindakan menghalangi orang dari jalan Allah.

39 Muhammad Quraish Shihab, Tafsir Al-Misbah: Pesan, Kesan dan Keserasian Alquran, vol, 1 (Jakarta: Lentera Hati, 2009), 460.

${ }^{40}$ Muhammad 'Ali Al-Ṣābūni, Șafwat al-Tafasìir, vol. 1 (Beirut: Dār al-Fikr, t.t), 291.
} 
muslimin. ${ }^{41}$ Kezaliman dan penindasan yang dilakukan oleh kaum musyrik yang mengancam eksistensi Islam diizinkan untuk melawannya. Penjelasan ayat di atas adalah bukti bahwa izin perang tersebut lantaran usaha umat Islam dalam melawan kezaliman manusia dan sebagai upaya dalam meneguhkan ketauhidan kepada Allah, bukan dalam rangka untuk menyebarkan Islam. Hal tersebut sebagaiamana dijelaskan oleh Ibn Jarir al-Ṭabari bahwa Allah mengizinkan orang-orang mukmin untuk berperang melawan kaum musyrik karena mereka menindas kaum mukmin. ${ }^{42}$

Adapun menurut al-Zamakhshari dan al-Baydāwi, diizinkannya perang dalam ayat tersebut setelah diturunkannya ayat- ayat yang melarang untuk melakukan perang, ${ }^{43}$ karena usaha untuk memaafkan dan bersabar tidak membuat kaum kafir berhenti melakukan penyiksaan. Izin untuk melakukan qităl dengan beberapa tahap didahului oleh perintah untuk menyampaikan pada lawan bahwa mereka diberi opsi untuk damai atau memerangi sebagaimana dalam QS. al-Anfal [8]: 38. Demikian juga perang diizinkan setelah perjanjian damai dikhianati oleh lawan. Selama perjanjian damai masih berlangsung maka peperangan dilarang.

\section{Hadis-Hadis Kunci tentang Qitāl}

Hadis-hadis Nabi tentang qitāl lebih variatif dan beragam, dibanding dengan ayat Alquran, bahkan cenderung provokatif. Diantaranya, hadis tentang perintah melakukan qitäl terhadap orangorang kafir atau murtad, hadis tentang menegakkan kalimat Allah dengan berperang, hadis tentang surga di bawah kilatan pedang, dan hadis yang menjelaskan tentang dibolehkannya melakukan tipu daya dalam peperangan dan lain sebagainya. Maka dari itu, menjadi sebuah keniscayaan untuk memahami hadis-hadis tersebut dengan benar agar tidak bertentangan dengan ruh Islam itu sendiri, yaitu raḅmat li alálamin.

Menurut Hasan Asy'ari Ulama'i, hadis-hadis qitāl di atas harus dipahami secara kontekstual dan mengacu pada prinsip-prinsip qitāl

${ }^{41}$ Farri Chatul Liqok, "Enkulturasi al-Quran \& Radikalisme Agama," dalam Al-Iman Jurnal Keislaman dan Kemasyarakatan, vol. 3, no. 2 (2019), 280.

42 Ibn Jarir al-Ṭabarì, Jämi al-Bayān fì Ta'mīl Ayy al-Qur'an, vol. 5 (Beirut: Mu'assasat al-Risālah, 1994), 321.

43 'Abdullāh b. Amr b. Muhammad al-Shirāzi al-Bayḍawi, Anwār al-Tanqīl wa Asrār al-Ta'wīl, vol. 4 (Bairut: Dār Iḥyā' al-Turāth al-'Arabì, t.th.), 73. 


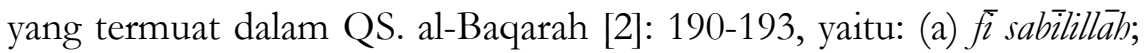
(b) dilancarkan terhadap orang-orang yang memerangi (alladhin yuqätilünakum); (c) tidak melampaui batas (wa là ta'taddū); (d) dengan kesungguhan atau keberanian; (e) tidak melakukannya di masjid alharam, kecuali mereka (lebih dulu) memerangi di tempat itu; (f) berhenti memerangi kalau mereka berhenti memusuhi; dan (g) sampai tidak ada fitnah lagi dan tegaknya ketaatan kepada Allah.

Hadis tentang perintah melakukan qitäl terhadap orang-orang kafir atau murtad terekam dalam beberapa kitab hadis, baik dalam

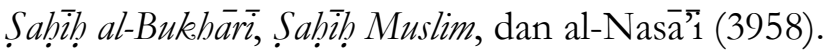

"Bahwa Abū Hurayrah berkata; "Setelah Rasulullah wafat yang kemudian Abū Bakr menjadi khalifah maka beberapa orang Arab ada yang kembali menjadi kafir (dengan enggan menunaikan zakat). Maka (ketika Abū Bakr hendak memerangi mereka), 'Umar b. al-Khattāab bertanya: 'Bagaimana anda memerangi orang padahal Rasulullah telah bersabda: 'Aku diperintahkan untuk memerangi manusia hingga mereka mengucapkan là iläha illā Allāh. Maka barang siapa telah mengucapkannya berarti terlindunglah dariku darah dan hartanya kecuali dengan haknya, sedangkan perhitungannya ada pada Allah.' Maka Abū Bakr berkata: 'Demi Allah, aku pasti akan memerangi siapa yang memisahkan antara kewajiban salat dan zakat, karena zakat adalah hak harta. Demi Allah, seandainya mereka enggan membayarkan anak kambing yang dahulu mereka menyerahkannya kepada Rasulullah, pasti akan aku perangi mereka disebabkan keengganan itu. 'Berkata, 'Umar al-Khattāăb: 'Demi Allah, ketegasan ini tidak lain selain Allah telah membukakan hati Abū Bakr dan aku menyadari bahwa dia memang benar."

Hadis ini harus difahami secara jeli sebab hadis ini dapat menyebabkan salah paham apabila dipahami secara tekstual. Hadis ini pada dasarnya bukan untuk memerangi orang kafir atau murtad, akan tetapi hadis ini menjelaskan tentang penegakan undang-undang dan hukum. Hadis ini muncul karena peristiwa diancamnya 'Uthmān b. 'Affan oleh musuh dan dia akan dibunuh. Kemudian beliau menceritakan pesan Nabi bahwa tidak boleh darah Muslim ditumpahkan, kecuali karena murtad (hukuman bagi mereka membahayakan umat Islam dalam peperangan saat itu, sebab orang kafir yang tidak memerangi juga tidak boleh diperangi), berzina (saat itu hukumnya didera), atau membunuh (hukumnya qisass). 
Perintah memerangi orang kafir dan orang murtad pada hadis tersebut merupakan kelompok kafir yang memerangi Islam, bukan kelompok kafir yang tidak memerangi Islam. Sedangkan orang murtad yang perlu diperangi adalah mereka yang 'membahayakan' umat Islam. Jadi kafir dan murtad pada hadis tersebut tidak berlaku umum (semua kafir dan semua murtad) tapi ada kekhususan, yaitu kafir yang memusuhi Islam dan kemurtadan yang membahayakan umat Islam. ${ }^{44}$ Demikian juga qital dapat dilakukan jika ada upaya musuh merusak sebuah sistem kenegaraan yang sudah berjalan dengan baik, sebagaimana penunggak zakat masa oleh Abū Bakr.

Adapun hadis tentang kemuliaan menegakkan agama dalam peperangan di antaranya diriwayatkan oleh Abū Mūsā. Dari Abū Mūsā berkata,

"seorang laki-laki datang menemui Nabi dan bertanya, Wahai

Rasulullah, apakah yang disebut dengan perang $\bar{i}$ sabilillăh (di jalan Allah)? Sebab di antara kami ada yang berperang karena marah dan ada yang karena semangat?' Beliau lalu mengangkat kepalanya ke arah orang yang bertanya, dan tidaklah beliau angkat kepalanya, kecuali karena orang yang bertanya itu berdiri. Beliau lalu menjawab: 'Barang siapa berperang untuk meninggikan kalimat Allah, maka dia berperang di jalan Allah.” [HR. al-Bukhāri]

Hadis ini menjelaskan tentang penegakkan 'kalimat' Allah. Pada saat itu penegakkan 'kalimat' Allah dilakukan salah satunya dengan perang. Sebab kondisi umat Islam yang terjepit mengharuskan perang tersebut. Namun dalam konteks saat ini meninggikan 'kalimat' Allah dapat dilakukan dengan pembelaan terhadap kaum yang lemah. pengentasan kemiskinan, konservasi lingkungan. Itu lebih sesuai dan selaras dengan pesan Islam. ${ }^{45}$

Demikian juga riwayat dari Sa⿳i 'Umar keluar menemui kami, lalu seseorang bertanya; "Bagaimana pendapatmu tentang memerangi fitnah? Ibn 'Umar menjawab; 'Tahukah kamu apa yang dimaksud fitnah? Nabi memerangi orang-

44 Muhammad Ansor, "Islam Awal, Riddah, dan Praksis Kebebasan Beragama: Reinterpretasi Hadis Man Baddal Dinah Faqtuluh," dalam Mutawatir: Jurnal Keilmuan Tafsir Hadith, vol. 5, no. 2 (2015).

45 Ahmad Hasan Asy'ari Ulama'I, “Membaca Ulang Hadis-Hadis Tentang Jihad, Perang (Qitā $)$, Kekerasan ( Unf), Teror (Irhäb) dan Fitnah Akhir Zaman: Pendekatan Kritis Kontekstual," dalam Reformulasi Ajaran Islam: Jihad, Khilafah dan Terorisme, ed. Muhammad Abdullah Darraz (Bandung: Mizan Pustaka, 2017), 438. 
orang musyrik, dan masuk ke dalam ligkungan mereka adalah fitnah, bukan seperti perang kalian dalam memerangi penguasa."

Hadis di atas menjelaskan bahwa qitäl dilakukan sesuai kondisi, seperti memerangi fitnah tidak bisa disamakan sebagaimana memerangi penguasa. Dalam konteks saat itu, fitnah dapat dihapus dengan perang atau qitäl. Namun dalam saat ini fitnah tidak dapat dilawan dengan qitäl, namun dengan klarifikasi, argumentasi dan penjelasan yang menyeluruh.

\section{Kesimpulan}

Berdasarkan ayat-ayat dan hadis di atas, maka dapat disimpulkan bahwa qităl atau perang dapat dilakukan adalah: (1) Qitall murni $\bar{f}$ sabilillăh, (2) Qitäl ditegakkan sebab diperangi terlebih dahulu, (3) Qitäl tidak diperbolehkan di tempat ibadah, baik tempat ibadah umat Islam atau tempat ibadah non-Islam, (4) Qitāl bertujuan untuk menghilangkan fitnah, (5) Qitäl tidak diperbolehkan mengorbankan umat Muslim yang lain. Adapun etika qitäl berdasarkan Alquran dan hadis adalah: (1) Qitäl tidak diperbolehkan melapaui batas, (2) Menghentikan perang apabila musuh sudah tidak berdaya, (3) Dalam Qitäl harus taat asas (peraturan); dan kesepakatan, (4) Qitäl bukan untuk merusak.

\section{Daftar Pustaka}

Ansor, Muhammad. "Islam Awal, Riddah, dan Praksis Kebebasan Beragama: Reinterpretasi Hadis Man Baddal Dinah Faqtuluh." Mutawatir: Jurnal Keilmuan Tafsir Hadith, vol. 5, no. 2 (2015).

Armstrong, Karen. Muhammad A Biography of the Prophet. London: Victor Gollancz, 1995.

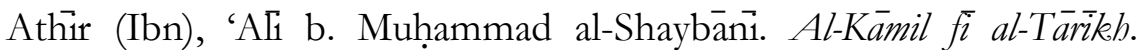
Beirut: Dār al-Ṣàdr, 1979.

Baydāwīi (al), 'Abdullāh b. Amr b. Muhammad al-Shirāzi. Anwār alTanzịl wa Asrār al-Ta'wīl. Beirut: Dār Ihyā', al-Turāth al-'Arabi, t.t.

Būṭi (al), Muhammad Ramad̄ān. Al-Jihäd fì al-Isläm: Kayf Nafhamuh wa Numärisuh. Libanon: Dār al-Fikr al-Mu'àsir, 1993.

Bukhāri [al], Muhammad b. Ismā̄ill. Șaḥiḩ al-Bukhārì. Beirut: Dār alFikr, 1994. 
Dahlan, Abdul Aziz (ed.). Ensiklopedi Hukum Islam. Jakarta: Ichtiar Baru Van, 1996.

Gabriel, Mark A. Islam and Terrorism; What the Qur'an Really Teaches about Christianity, Violence and the Goals of Islamic jibad. Florida: Charisme House, 2002.

Hamka. Tafsir Al-Azhar. Jakarta: Pustaka Panjimas, 1986.

Hanafi, Hasan. Dirasàt Islamiyah. Kairo: al-Maktabat al-Anjila alMișriyah, 1987.

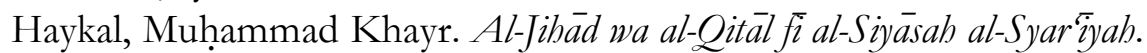
Damaskus: Dār al-Bayāriq li al-Ṭibā'ah, 1996.

Hidayat, Komaruddin. Memahami Babasa Agama: Sebuab Kajian Hermeneutik, Jakarta: Paramadina, 1996.

Hishām (Ibn), Muhammad 'Abd Mālik. Al-Sīrah al-Nabawìyah. ed. Jamāl Thābit, dkk. Kairo: Dār al-Ḥadith, 2004.

Liqok, Farri Chatul. "Enkulturasi al-Quran \& Radikalisme Agama." AlIman Jurnal Keislaman dan Kemasyarakatan, vol. 3, no. 2 (2019).

Ma'arif, Ahmad Syafi'i. "Pengantar: Mencari Akar EkstremismeTerorisme," dalam Azyumardi Azra. Reformulasi Ajaran Islam: Jihad, Khilafah dan Terorisme, diedit oleh Muhammad Abdullah Darraz. Bandung: Mizan Pustaka, 2017.

Ma'luf, Louis. Al-Munjid fí al-Lughah wa al-A 'lam. Beirut: Dār alMashriq, 1992.

Madjid, Nurcholish, dkk. Fiqih Lintas Agama. Jakarta: Yayasan Wakaf Paramadina, 2005.

Muna, Moh. Nailul. "Ragam Pemaknaan Jihad dalam Kitab Fath alBârî dan Irshâd al-Sârî." Mutawatir: Jurnal Keilmuan Tafsir Hadith, vol. 7, no. 2 (2017).

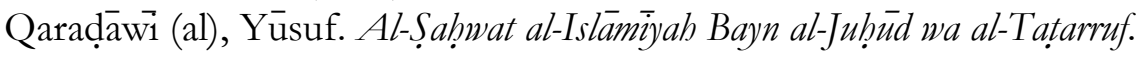
Kairo: Dār al-Shurūq, 2001.

Qushayrì (al), Abū Ḥusayn Muslim b. Hajjàj. Șaḥị Muslim. Beirut: Dār al-Fikr, 1993.

Rahman, Fazlur. Islam and Modernity: Transformation of an Intellectual Tradition. Chichago: The University of Chichago Press, 1982.

Rohman, Izza. "Jihad dan Qitāl dalam Alquran," dalam Reformulasi Ajaran Islam: Jihad, Khilafah dan Terorisme. Diedit oleh Muhammad Abdullah Darraz. Bandung: Mizan Pustaka, 2017.

Șābūni, Muhammad 'Ali. Șafwat al-Tafasìr. Beirut: Dār al-Fikr, t.t.

Saeed, Abdullah. Alquran Abad 21: Tafsir Kontekstual. Diterjemahkan oleh Ervan Nurtawab. Bandung: Mizan, 2016. 
Pengantar Studi Al-Qur'an. Diterjemahkan oleh Shulkhah \& Sahiron Syamsuddin (Yogyakarta: Baitul Hikmah Press, 2016). Saputra, Rangga Eka. Api dalam Sekam: Keberagamaan Generasi Z, diedit oleh Endi Aulia Garadian. Jakarta: PPIM UIN Syarif Hidayatullah, 2018.

Shātịīi (al), Abū Isḥaq. Al-Muwafaqāt fì Ușull al-Sharīah. Kairo: alMaktabat al-Tijariyah al-Kubrā, t.t.

Shaltūt, Maḥmūd. Al-Qur'an wa al-Qitäl. Beirut: Dār al-Fath, 1983.

Shihab, Muhammad Quraish. Membumikan Alquran. Bandung: Mizan, 2002.

Shihab, Muhammad Quraish. Tafsir Al-Misbah: Pesan, Kesan dan Keserasian Al-Qur'an. Jakarta: Lentera Hati, 2009.

Suryadi. "Rekonstruksi Metodologi Pemahaman Hadis Nabi," dalam ESENSLA: Jurnal Ilmu-Ilmu Ushuluddin, vol. 2, no. 1. (2001).

Syamsudin, Sahiron. "Pesan Damai di Balik Seruan Jihad," dalam Islam, Tradisi dan Peradaban, diedit oleh Sahiron Syamsudin. Yogyakarta: Bina Mulia Press, 2012.

Tabarì (al), Ibn Jarir. Jami‘ al-Bayān fī Ta'wīl Ayy al-Qur'an. Beirut: Mu'assasat al-Risālah, 1994.

Ulama'i, Ahmad Hasan Asy'ari. "Membaca Ulang Hadis-Hadis Tentang Jihad, Perang (Qitā $)$, Kekerasan (Unf), Teror (Irhāb) dan Fitnah Akhir Zaman: Pendekatan Kritis Kontekstual," dalam Reformulasi Ajaran Islam: Jihad, Khilafah dan Terorisme, diedit oleh Muhammad Abdullah Darraz. Bandung: Mizan Pustaka, 2017.

Umam, Saiful dan Yunita Faela Nisa. "Pelita yang Meredup: Potret Keberagamaan Guru Indonesia." Launching Hasil Survei PPIM 2018, Jakarta: Hotel Le Meridien. 2018.

Umar, Nasarudin. "Alquran di Mata Mantan Intelektual Muslim: Ibn Warraq dan Mark A. Gabriel." Jurnal Studi Al-Qur'an, vol. 1, (2006).

Wasman. "Pemahaman Hadis-Hadis Konfrontatif terhadap Yahudi dan Nasrani”. Disertasi. UIN Sunan Kalijaga Yogyakarta, 2014.

Yusuf, Muhammad. Metode Dan Aplikasi Pemaknaan Hadis. Yogyakarta: Sukses Offset, 2008.

Zakaryā (Ibn), Abū al-Ḥusayn Ahṃad b. Fāris. Mưjam Maqāyis alLughah. Beirut: Dār Ittiḥād al-'Arabì, 2002. 